Editorial

\title{
How Populism and Polarization Affect Europe's Liberal Democracies
}

\author{
Heidi Schulze ${ }^{1, *}$, Marlene Mauk $^{1}$ and Jonas Linde ${ }^{2}$ \\ ${ }^{1}$ GESIS-Leibniz Institute for the Social Sciences, 50667 Cologne, Germany; E-Mails: heidi.schulze@gesis.org (H.S.), \\ marlene.mauk@gesis.org (M.M.) \\ 2 Department of Comparative Politics, University of Bergen, 5020 Bergen, Norway; E-Mail: jonas.linde@uib.no \\ * Corresponding author
}

Submitted: 10 July 2020 | Published: 17 July 2020

\begin{abstract}
In recent years, two phenomena have put Europe's liberal democracies under strain: populism and polarization. The rise of populist parties, the increasing radicalization of publics and political discourse, as well as the expansion of hyperpartisan media have caused concern among observers and citizens alike. While lively academic discussions have revolved around the causes of these phenomena, research regarding their real-world consequences has been sparse. This thematic issue wants to address this gap in the literature and contribute to developing strategies for mitigating potential threats populism and polarization may pose to liberal democracies. To this end, it examines how populism and polarization affect citizens across Europe. It links research on audiences of hyperpartisan media with work on elite-induced polarization, populist conceptions of democracy, election results and support for the democratic system, and policy-making by populist governments.
\end{abstract}

\section{Keywords}

democracy; hyperpartisan media; polarization; political support; populism

\section{Issue}

This editorial is part of the issue "Populism and Polarization: A Dual Threat to Europe's Liberal Democracies?" edited by Jonas Linde (University of Bergen, Norway), Marlene Mauk (GESIS-Leibniz Institute for the Social Sciences, Germany) and Heidi Schulze (GESIS—Leibniz Institute for the Social Sciences, Germany).

(C) 2020 by the authors; licensee Cogitatio (Lisbon, Portugal). This article is licensed under a Creative Commons Attribution 4.0 International License (CC BY).

In recent years, European liberal democracies have increasingly come under strain. In particular, the rise of populist and sometimes radical parties, increasing political polarization and radicalization of publics and political discourse, and the expansion of alternative, hyperpartisan news media fostering antagonism and propagating ideas incompatible with liberal democracy have been cause for concern. With countries such as Poland and Hungary already exhibiting manifest democratic recessions (Lührmann, Grahn, Morgan, Pillai, \& Lindberg, 2019; Lührmann et al., 2018), scientific and public discourse alike have mainly revolved around two worrying phenomena that may endanger the stability of democracy: populism and polarization (see Inglehart \& Norris, 2017).

Across Europe, predominantly right-wing populist parties have not only entered national and regional parliaments but also begun exercising executive power in various governments, often dominating the political discourse in their respective countries (Mudde, 2016; Rooduijn, 2015). With radical-right and, to a lesser extent, radical-left populist parties advocating extreme policy positions and, at the same time, nourishing distrust toward traditional parties and media, both parties and voters have become increasingly polarized, and divisions between political camps appear to be growing deeper (Galston, 2018; lyengar \& Westwood, 2015). These trends seem to be fueled, in part, by digital communication: Populist actors use online media very efficiently to spread their messages (Engesser, Ernst, Esser, \& Büchel, 2017; Gerbaudo, 2017; Stier, Posch, Bleier, \& Strohmaier, 2017), and (hyper-)partisan media reinforce populist, radical, and anti-democratic ideas through repetition across various online networks and social media 
platforms (Prior, 2013; Starbird, 2017). These developments beg the question, how are these changes affecting societies and the liberal democratic order? In particular, are populism and polarization serious threats to liberal democracy?

Populism, on the one hand, can be defined as:

An ideology that considers society to be ultimately separated into two homogeneous and antagonistic groups, 'the pure people' versus 'the corrupt elite,' and which argues that politics should be an expression of the volonté générale (general will) of the people. (Mudde, 2004, p. 543)

Thus, in itself, it may not necessarily be seen as a threat to democracy (Canovan, 1999). However, populist parties typically adopt either a radical-right or radical-left host ideology, criticizing liberal democratic procedures and furthering the political polarization of both the party system and the public. Even more importantly, by stylizing 'the people' as a homogeneous group, populism not only rejects the idea of counter-majoritarian institutions, such as minority rights, but is in itself inherently antipluralistic, challenging the very core of liberal democracy (Galston, 2018; Müller, 2016; Pappas, 2019).

Polarization, on the other hand, is defined as either the state or the process of opinions being or becoming more opposed (DiMaggio, Evans, \& Bryson, 1996, p. 693). Given this definition, polarization might not necessarily be seen as a threat to democracy. After all, a plurality of political views is one of the hallmarks of liberal democracy (cf. Dahl, 1989). However, if polarization becomes too extreme, it is likely to result in social and political conflict, making political compromise, let alone consensus, almost impossible, thereby hindering the smooth functioning of the democratic political system (DiMaggio et al., 1996; Hetherington \& Rudolph, 2015; lyengar, Lelkes, Levendusky, Malhotra, \& Westwood, 2019). Both populism and polarization can thus be considered serious threats to the liberal democratic order established in Europe after World War II.

From a normative liberal democratic point of view, then, the electoral success of (right-wing) populist parties critical of liberal democracy, and the political division and radicalization of elites and publics are clearly undesirable and alarming. Yet, while lively academic discussions as well as public debates have revolved around the causes of these phenomena (see, e.g., Doyle, 2011; Ivarsflaten, 2008; Lubbers, Gijsberts, \& Scheepers, 2002; March \& Rommerskirchen, 2014; Rooduijn, 2018; Van Hauwaert \& van Kessel, 2018; Visser, Lubbers, Kraaykamp, \& Jaspers, 2014), research regarding their real-world consequences has been sparse. This thematic issue addresses these potential threats by examining how populism and polarization affect citizens across Europe. Ordinary citizens and their attitudes toward the political system are central ingredients of a stable and well-functioning democracy (e.g., Easton, 1965;
Hetherington, 1998). As long as citizens' support for the present political system-liberal democracy-remains high even in light of increasing populism and polarization, we have reason to be optimistic about the future: Populist and radical parties should not be able to dismantle democracy easily against the will of the public. The contributions in this thematic issue therefore focus on how ordinary citizens react to populism and polarization and aim to identify the conditions under which populism and polarization exert their least detrimental effects on citizens' attitudes.

To this end, Schulze (2020) focuses on the role of online news media as drivers of radical-right populist attitudes and explores the characteristics of the audiences of right-wing alternative online media, also referred to as hyperpartisan media. Drawing on the 2019 Reuters Digital News Survey, Schulze presents a cross-national analysis of right-wing alternative media use in Northern and Central Europe. The analysis shows that political interest and a critical stance toward immigration, accompanied by a skeptical assessment of news quality, in general, and distrust-especially in public service broadcasting media-as well as the use of social media as a primary news source, function as the strongest predictors of alternative online news consumption. Her findings suggest that right-wing alternative online media should not be dismissed as a peripheral phenomenon, but rather must be considered as relevant multipliers and distributors of populist narratives with high mobilizing and polarizing potential.

Berntzen (2020) adds to the theme of this thematic issue by studying the effects of political and normative conflicts initiated by populist radical-right parties. More precisely, he investigates whether and to what extent voters are affected by attacks of populist radicalright parties on their political opponents. To differentiate between authoritarian and non-authoritarian voters, the four-item child rearing values index measure of authoritarian predispositions is employed. Using a surveybased experimental design that relies on data from the Norwegian Citizen Panel, Berntzen shows that authoritarian and non-authoritarian voters simultaneously respond to high-intensity political conflict. From the analyses, he concludes that conflict initiated by populist radical-right parties functions as a driver of personalitybased, affective sorting of citizens and thus contributes to polarization.

Making a novel contribution to the burgeoning research on how the continuous success of populist parties affects public notions of democracy, Heinisch and Wegscheider (2020) deal with the tension between populism and democracy. Drawing on survey data from Austria and Germany, they provide an empirical analysis of how different types of populist attitudes and four types of democratic decision-making interact. Taking into account that populism is often attached to a radicalright or radical-left host ideology, their findings show that populism and radical host ideologies tap into dif- 
ferent dimensions of democracy. Populist attitudes are associated with negative views toward representative democracy and pluralism, while support for majority rule and deliberative procedures are shaped by the radicalright and radical-left host ideologies. Interestingly, and perhaps somewhat surprising, populists favor decisionmaking based on the general will of the people (antipluralism), while at the same time are not very attracted to strict majority rule and restriction of minority rights (which, on the other hand, are attractive to people with nativist and authoritarian attitudes).

Turning to the effects of the rise of populist parties on citizen attitudes, Mauk (2020) analyzes how the electoral success of populist parties affects European citizens' trust in core democratic institutions. Diverging from the individual-level literature, which shows a negative relationship between populist party support and political trust, she suggests that macro-level populist party success may increase political trust among the general public. She further proposes, as well as demonstrates empirically for 23 European democracies, that this correctiveforce effect is particularly pronounced in democracies that do actually lend themselves to populist criticism: The electoral success of populist parties only leads to increased citizen trust in countries with deficient democratic quality, weak corruption control, and meagre economic performance. In countries with high democratic quality, effective corruption control, and high economic performance, in contrast, populist party success has no substantive effect on political trust.

Building on the well-established finding that citizens who voted for the winning camp express higher satisfaction with democracy than those who voted for the losing camp, Nemčok (2020) examines how big of a boost in satisfaction with democracy election winners experience, and whether the size of this boost is conditional on party characteristics. Utilizing 17 surveys from 13 European countries in which an election resulted in a change in government, Nemčok shows that differences in party vote shares and voters' feelings of closeness to a party have only negligible effects on the boost experienced by election winners. However, his results also demonstrate that voters who feel close to a particular party are generally more satisfied with democracy than those without a party affiliation, regardless of whether their party won the election or not. This latter finding relates to Mauk's contribution in that it points to the observation that citizens seeing their preferences as represented within the political system can increase their support for the democratic system. Both studies promote the idea that perceived or actual representation of citizens' preferences can help reconcile them with democracy, and thereby indicate a potential avenue for (re-)integrating populist and radical citizens into the political system.

Concluding the thematic issue, Bartha, Boda, and Szikra (2020) take a look at populists in government. An increasing number of studies have set out to investigate the policy effects of governments that include populist parties. In their article, "When Populist Leaders Govern: Conceptualising Populism in Policy Making," they provide an analysis of policy-making by the first populist radical-right majority government in Europe-the Fidesz government in Hungary. The authors construct an ideal type of populist policy-making and use congruence analysis to investigate to what extent social policy in post2010 Hungary (2010-2018) conforms with the ideal type. Focusing on policy content, process, and discourse, they find a strong degree of congruence between the policymaking patterns of the Orbán government and the ideal type of populist policy-making.

Overall, the contributions paint a multifaceted picture of how populism and polarization affect European liberal democracies. On the one hand, fueled by digital media, European societies are in danger of becoming increasingly populist and polarized, and this development is accompanied by attitudes and conceptions challenging to liberal democracies. On the other hand, the representation of populist parties within the political system can help mitigate citizens' disenchantment with the liberal democratic system. In the end, populism and polarization come with numerous detrimental by-products: the brutalization of political debate, the spread of disinformation, and, not least, an increased propensity to violence against 'the other,' which are only the most obvious problems. More fundamental changes in citizen perceptions of and attitudes toward liberal democracy may additionally lead to a turning away from the hard-earned achievements of modern democracies: minority rights, rule of law, and separation of powers.

\section{Acknowledgments}

This thematic issue was accompanied by the 5th EUROLAB Authors' Conference in Cologne, titled “Populism and Polarization: A Dual Threat to Europe's Democracies?" The majority of the articles published in this thematic issue were presented and discussed during this conference. We would like to thank all authors, reviewers, and discussants who contributed to the conference and this thematic issue, as well as the Fritz Thyssen Foundation for their generous financial support of the conference.

\section{Conflict of Interests}

The authors declare no conflict of interests.

\section{References}

Bartha, A., Boda, Z., \& Szikra, D. (2020). When populist leaders govern: Conceptualising populism in policy making. Politics and Governance, 8(3), 71-81.

Berntzen, L. E. (2020). How elite politicization of terror impacts sympathies for partisans: Radical right versus social democrats. Politics and Governance, 8(3), 19-31. 
Canovan, M. (1999). Trust the people! Populism and the two faces of democracy. Political Studies, 47(1), 2-16. https://doi.org/10.1111/1467-9248.00184

Dahl, R. A. (1989). Democracy and its critics. New Haven, $\mathrm{CT}$, and London: Yale University Press.

DiMaggio, P., Evans, J., \& Bryson, B. (1996). Have American's social attitudes become more polarized? American Journal of Sociology, 102(3), 690-755. https:// doi.org/10.1086/230995

Doyle, D. (2011). The legitimacy of political institutions. Comparative Political Studies, 44(11), 1447-1473. https://doi.org/10.1177/0010414011407469

Easton, D. (1965). A systems analysis of political life. New York, NY: Wiley.

Engesser, S., Ernst, N., Esser, F., \& Büchel, F. (2017). Populism and social media: How politicians spread a fragmented ideology. Information, Communication \& Society, 20(8), 1109-1126. https://doi.org/10.1080/ 1369118X.2016.1207697

Galston, W. A. (2018). The populist challenge to liberal democracy. Journal of Democracy, 29(2), 5-19. https://doi.org/10.1353/jod.2018.0020

Gerbaudo, P. (2017). Social media and populism: An elective affinity? Media, Culture \& Society, 40(5), 745-753. https://doi.org/10.1177/01634437187721 92

Heinisch, R., \& Wegscheider, C. (2020). Disentangling how populism and radical host ideologies shape citizens' conceptions of democratic decision-making. Politics and Governance, 8(3), 32-44.

Hetherington, M. J. (1998). The political relevance of political trust. The American Political Science Review, 92(4), 791-808. https://doi.org/10.2307/2586304

Hetherington, M. J., \& Rudolph, T. J. (2015). Why Washington won't work. Chicago, IL, and London: The University of Chicago Press.

Inglehart, R., \& Norris, P. (2017). Trump and the populist authoritarian parties: The silent revolution in reverse. Perspectives on Politics, 15(2), 443-454. https://doi. org/10.1017/S1537592717000111

Ivarsflaten, E. (2008). What unites right-wing populists in Western Europe? Comparative Political Studies, 41(1), 3-23. https://doi.org/10.1177/ 0010414006294168

Iyengar, S., Lelkes, Y., Levendusky, M., Malhotra, N., \& Westwood, S. J. (2019). The origins and consequences of affective polarization in the United States. Annual Review of Political Science, 22(1), 129-146. https://doi.org/10.1146/annurev-polisci-051117073034

lyengar, S., \& Westwood, S. J. (2015). Fear and loathing across party lines: New evidence on group polarization. American Journal of Political Science, 59(3), 690-707. https://doi.org/10.1111/ajps.12152

Lubbers, M., Gijsberts, M., \& Scheepers, P. (2002). Extreme right-wing voting in Western Europe. European Journal of Political Research, 41(3), 345-378. https://doi.org/10.1111/1475-6765.00015
Lührmann, A., Grahn, S., Morgan, R., Pillai, S., \& Lindberg, S. I. (2019). State of the world 2018: Democracy facing global challenges. Democratization, 26(6), 895-915. https://doi.org/10.1080/ 13510347.2019 .1613980

Lührmann, A., Mechkova, V., Dahlum, S., Maxwell, L., Olin, M., Petrarca, C. S., . . L Lindberg, S. I. (2018). State of the world 2017: Autocratization and exclusion? Democratization, 25(8), 1321-1340. https://doi.org/ 10.1080/13510347.2018.1479693

March, L., \& Rommerskirchen, C. (2014). Out of left field? Explaining the variable electoral success of European radical left parties. Party Politics, 21(1), 40-53. https://doi.org/10.1177/1354068812462929

Mauk, M. (2020). Rebuilding trust in broken systems? Populist party success and citizens' trust in democratic institutions. Politics and Governance, 8(3), 45-58.

Mudde, C. (2004). The populist zeitgeist. Government and Opposition, 39(4), 541-563. https://doi.org/ 10.1111/j.1477-7053.2004.00135.x

Mudde, C. (2016). Europe's populist surge: A long time in the making. Foreign Affairs, 95(6), 25-30.

Müller, J.-W. (2016). What is populism? Philadelphia, PA: University of Pennsylvania Press.

Nemčok, M. (2020). The effect of parties on voters' satisfaction with democracy: Evidence from discontinuity design applied to European social survey. Politics and Governance, 8(3), 59-70.

Pappas, T. S. (2019). Populism and liberal democracy: $A$ comparative and theoretical analysis. Oxford: Oxford University Press.

Prior, M. (2013). Media and political polarization. Annual Review of Political Science, 16(1), 101-127. https:// doi.org/10.1146/annurev-polisci-100711-135242

Rooduijn, M. (2015). The rise of the populist radical right in Western Europe. European View, 14(1), 3-11. https://doi.org/10.1007/s12290-015-0347-5

Rooduijn, M. (2018). What unites the voter bases of populist parties? Comparing the electorates of 15 populist parties. European Political Science Review, 10(3), 351-368. https://doi.org/10.1017/ S1755773917000145

Schulze, H. (2020). Who uses right-wing alternative online media? An Exploration of audience characteristics. Politics and Governance, 8(3), 6-18.

Starbird, K. (2017). Examining the alternative media ecosystem through the production of alternative narratives of mass shooting events on Twitter. In Proceedings of the Eleventh International AAAl Conference on Web and Social Media (pp. 230-239). Palo Alto, CA: AAAI Press. Retrieved from https://www. aaai.org/ocs/index.php/ICWSM/ICWSM17/paper/ viewPaper/15603

Stier, S., Posch, L., Bleier, A., \& Strohmaier, M. (2017). When populists become popular: Comparing Facebook use by the right-wing movement pegida and german political parties. Information, Communica- 
tion \& Society, 20(9), 1365-1388. https://doi.org/ 10.1080/1369118X.2017.1328519

Van Hauwaert, S. M., \& van Kessel, S. (2018). Beyond protest and discontent: A cross-national analysis of the effect of populist attitudes and issue positions on populist party support. European Journal of Political Research, 57(1), 68-92. https://doi.org/10.1111/
1475-6765.12216

Visser, M., Lubbers, M., Kraaykamp, G., \& Jaspers, E. (2014). Support for radical left ideologies in Europe. European Journal of Political Research, 53(3), 541-558. https://doi.org/10.1111/1475-6765. 12048

\section{About the Authors}

Heidi Schulze is a Doctoral Researcher at the Department of Media and Communication at LMU Munich (Germany) and a Research Associate at GESIS-Leibniz Institute for the Social Sciences. At LMU, she is part of the research lab of Prof. Dr. Rieger and works in an interdisciplinary research project on online radicalization employing computational methods. In her thesis, Ms. Schulze studies characteristics and audiences of alternative online media and hyperpartisan news websites.

Marlene Mauk is a Research Associate in political science at GESIS-Leibniz Institute for the Social Sciences, Cologne. She holds a PhD in Comparative Politics from Mainz University. Her research interests lie in the field of political culture, with a focus on the comparison between democracies and autocracies; among other topics, she studies political trust and its sources, political value orientations, and various aspects of democratic quality. She is the Author of Citizen Support for Democratic and Autocratic Regimes (2020, Oxford University Press).

Jonas Linde is Professor of Comparative Politics at University of Bergen, Norway. His research interests are within the fields of political support, public opinion, comparative corruption, democratization, and post-communist politics. His research has been published in journals such as European Journal of Political Research, Political Studies, Party Politics, The Journal of Politics, Democratization, and Government and Opposition. 